\title{
Impact of Different Mixing Ratios on Biomethanation of Cattle Blood and Rumen Content
}

\author{
Gyasi, P. ${ }^{1}$, Selormey, G. M. ${ }^{3}$, Darkwah, L. ${ }^{2 *}$, Amano, K. O. A. ${ }^{2}$ and Quarshie, S. D. ${ }^{4}$ \\ ${ }^{1}$ Mechanical Engineering Department, K.N.U.S.T., Kumasi, Ghana \\ ${ }^{2}$ Otto von Guericke University Magdeburg, Faculty of Process and Systems Engineering, Dept. of Plant Design and Process \\ Safety, Universitätsplatz 2, 39106 Magdeburg \\ ${ }^{3}$ Agricultural Engineering Department, K.N.U.S.T., Kumasi, Ghana \\ ${ }^{4}$ College of safety and environment engineering, Shandong Uni. Of Sci. and Tech., China \\ *Corresponding Author
}

\begin{abstract}
Biomethane produced by anaerobic digestion of organic waste is a renewable and sustainable energy that can supplement global energy needs. Existing literature shows that different mixing ratios of the same co-substrates have an impact on biomethane production. In this study, the impact of different mixing ratios of cattle blood and rumen contents on biomethane production was investigated. The physicochemical characteristics of seven samples with different blood and rumen contents were determined. Their biomethane yield was then assessed in laboratory-scale batch digesters at $37^{\circ} \mathrm{C}$ (mesophilic). The biomethane yields of the samples gave a mean value of $11.25 \pm 13.34$ which indicates significant variability $(p<0.05)$. The sample containing $10 \mathrm{ml}$ of bovine blood and $50 \mathrm{ml}$ of rumen contents $\left(S_{6}\right)$ gave the highest biomethane yield and can be considered for optimization of biomethane production from these feedstocks.
\end{abstract}

Keywords:- Co-digestion, biomethane, mixing ratios, cattle blood, rumen content

\section{INTRODUCTION}

$\mathrm{E}$ nergy is an inevitable resource in socio-economic development. However, the supply of fossil fuels, which are currently the main global source of energy, is running out, while their regular use generates greenhouse gasses that contribute to climate change. It is therefore a global concern to search for alternative energy sources that are renewable and sustainable. Nevertheless, biomethane produced by anaerobic digestion (AD) of organic waste is a proven renewable and sustainable energy. Biomethane has a calorific value of $36 \mathrm{MJ} / \mathrm{m}^{3}$ and therefore can be combusted to produce thermal energy and electricity $[1,2]$.

The anaerobic digestion process involves four steps which are interdependent. These are hydrolysis, acidogenesis, acetogenesis and methanogenesis [3, 4]. In this process, microorganisms digest organic material for their growth and produce biogas which contains about $50-70 \%$ biomethane as a by-product [1,5]. Different organic wastes have different biomethane potentials. However, the suitability and biomethane potential of substrates depend on their physicochemical characteristics and operating conditions such as $\mathrm{pH}$, temperature, loading rate, pre-treatment and complete absence of molecular oxygen [6].
The activities of microorganisms involved in anaerobic digestion (AD) depend on the above factors. The biomethane producing bacteria (methanogenic bacteria) are sensitive to temperature, oxygen and $\mathrm{pH}[6,7]$. Temperature instability has a negative effect on biomethane production process. Fluctuations that do not exceed the following limits can be considered safe when operating AD processes: Psychrophilic range $\left( \pm 2{ }^{\circ} \mathrm{C} / \mathrm{h}\right)$, Mesophilic range $\left( \pm 1{ }^{\circ} \mathrm{C} / \mathrm{h}\right)$, Thermophilic range $\left( \pm 0.5^{\circ} \mathrm{C} / \mathrm{h}\right)[6]$. The $\mathrm{pH}$ of a substrate is a critical parameter that determines the success of the AD process. This is because outside the optimum $\mathrm{pH}$ range of 6.5 and 8.5 [8], methanogens are strongly inhibited. Therefore, the proper slurry $\mathrm{pH}$ must be maintained in the digester for stable biomethane production. [5, 3].

The $\mathrm{pH}$ depends on the Carbon - Nitrogen ratio ( $\mathrm{C} / \mathrm{N}$ ratio) of the substrate fed to the digester. $\mathrm{C} / \mathrm{N}$ is the ratio of the number of organic carbon atoms to the number of nitrogen atoms in the substrate. [3]. It determines the stability of the digestion process. Microorganisms feed on carbon as a source of energy and nitrogen to build cell structures. If the $\mathrm{C} / \mathrm{N}$ ratio is too high, the $\mathrm{pH}$ of the process drops rapidly due to the formation of fatty acids, which inhibits the methane-producing bacteria. If the ratio is too low, the process suffers from ammonia inhibition $[5,3]$. It is difficult to state the exact optimal $\mathrm{C} / \mathrm{N}$ ratio because it varies with different substrates and with process conditions. However, for optimized biomethane production, the $\mathrm{C} / \mathrm{N}$ ratio of the feedstock mixture should be between 20 and 30. Microorganisms consume carbon about 30 times faster than they use nitrogen, so they need a $\mathrm{C} / \mathrm{N}$ ratio closer to 30 . Table 1 shows the $\mathrm{C} / \mathrm{N}$ ratio of some organic materials $[9,5]$.

Table 1: $\mathrm{C} / \mathrm{N}$ of some organic materials

\begin{tabular}{|c|c|c|}
\hline Substrate & Nitrogen $(\%)$ & C/N ratio \\
\hline Chicken dung & 8 & $6-15$ \\
\hline Turkey litter & 2.6 & 16 \\
\hline Human use & $5-7$ & $5-10$ \\
\hline Pig manure & 3.1 & 14 \\
\hline Cow manure & 2.4 & 19 \\
\hline
\end{tabular}




\begin{tabular}{|c|c|c|}
\hline Sheep manure & 2.7 & 16 \\
\hline Slaughterhouse waste & $7-10$ & $2-4$ \\
\hline Horse manure & 1.6 & $25-30$ \\
\hline Whole carrot & 1.6 & 27 \\
\hline Potato top & 1.5 & 25 \\
\hline Raw sawdust & 0.11 & 511 \\
\hline Rotted sawdust & 0.25 & $200-500$ \\
\hline Rice hull & 0.3 & 121 \\
\hline Soybean meal & $7.2-7.6$ & $4-6$ \\
\hline Tomato & 3.3 & 12 \\
\hline Corn hubs & 0.6 & $56-123$ \\
\hline Corn husk & $0.6-0.8$ & $60-73$ \\
\hline Grass clipping & 2.1 & $12-19$ \\
\hline Water lily & 2.9 & 11.4 \\
\hline Algae & 1.9 & 100 \\
\hline Fallen leaves & 1 & 50 \\
\hline
\end{tabular}

Biomethane yield also depends on the total solids (TS) and volatile solids (VS) of the substrates. TS is the dry solids portion of the wet substrate after heating the substrate to a temperature of about $105 \mathrm{o}$ C. VS is a portion of TS, which is lost when the dry matter is combusted at $550 \mathrm{o} \mathrm{C}$ or $600 \mathrm{o}$ C. The total solids portion of the substrate is the volatile solids portion. It is the digestible portion of the substrate. It determines the concentration of the slurry introduced into a digester and the amount of biomethane produced from it per unit weight of slurry introduced into the digester $[5,3]$. The total solids and volatile solids of some substrates are shown in Table $2[10,9,11]$.

Table 2: The TS and VS content organic materials

\begin{tabular}{|c|c|c|}
\hline Substrate & TS (\%) & VS (\%TS) \\
\hline Rumen content (untreated) & $12-16$ & $85-88$ \\
\hline Cattle slurry & $5-12$ & 80 \\
\hline Chicken manure & $10-29$ & $67-77$ \\
\hline Brewery spent grain & $20-26$ & $80-95$ \\
\hline Corn Silage & $20-40$ & $94-97$ \\
\hline Municipal organic waste & $15-30$ & $80-95$ \\
\hline Sheep manure & $18-25$ & $80-85$ \\
\hline Human Faeces & $14-22$ & $79-84 ; 93$ \\
\hline Sewage sludge & $3-5$ & $75-85$ \\
\hline Cattle excreta & $25-30$ & $75-85$ \\
\hline Pig stomach content & $12-15$ & $80-84$ \\
\hline Pig manure & $20-25$ & $75-80$ \\
\hline Pig slurry & $3-8$ & $70-80$ \\
\hline
\end{tabular}

Studies have shown that biomethane production and process stability can be improved by co-digestion of high- carbon materials with low $\mathrm{C} / \mathrm{N}$ ratio substrates. Moreover, different mixing ratios of the same co-substrates lead to different biomethane yields $[12,13,14]$. The addition of nutrient medium to the substrate increases the adaptability of the microorganisms involved in the anaerobic digestion process [15]. [12], investigated the biogas potential of anaerobic codigestion of poultry slaughterhouse waste with sewage sludge. [16], evaluated the co-digestion process of different waste mixtures from agro-industrial activities. [17], studied the methane production, long-chain fatty acids (LCFAs) profile and predominant microorganisms in anaerobic digestion (AD) of lipid-rich swine slaughterhouse (SSW) waste. [18] investigated the biomethane production potential of slaughterhouse waste in the United States. [19] investigated the effects of varying the inoculum to waste ratio on the anaerobic treatment of slaughterhouse waste and proposes a cost-effective anaerobic treatment system.

Although cattle blood and rumen contents (which often constitute the majority of organic slaughterhouse waste) have been identified as suitable feedstock for biomethane production, their biomethane potential has not been investigated in relation to different mixing ratios [20,21, 22]. This work was carried out to fill this gap by evaluating the biomethane potential of cattle blood and rumen contents from Kumasi Abattoir Company Limited. The study helps in identifying a mixing ratio that increases biomethane production from these organic effluents from the abattoir, as well as highlighting the effects of different mixing ratios of the same co-substrates on biomethane.

\section{METHODS AND MATERIALS}

\subsection{Collection of Raw Material}

Cattle blood (fluid) and rumen contents (slurry) were collected at 9:00 am from the evisceration unit of Kumasi Abattoir Company Limited at Ahinsan in Kaase Industrial Area, Kumasi, Ghana. The blood of the cattle was collected in a clean, dry plastic bottle while the rumen contents were collected in a clean, dry plastic container. They were stored in a temperature-controlled ice chest and transported to Biotechnology Laboratory of Chemical Engineering Department at Kwame Nkrumah University of Science and Technology, Kumasi, Ghana for analysis.

\subsection{Experimental Set-up}

Seven samples were prepared for the study with different mixing ratios of cattle blood, rumen contents and nutrient medium. Each sample was analysed for its physicochemical characteristics and then digested in a 1- litre laboratory digester at a constant temperature of $37 \mathrm{o} \mathrm{C} \mathrm{(mesophilic)} \mathrm{under}$ anaerobic conditions to determine the biomethane yield. The digester system consisted of digesters, gas counter, infrared sensor (BlueSensBACCom 12) and BACVis software (see Figure 1). 


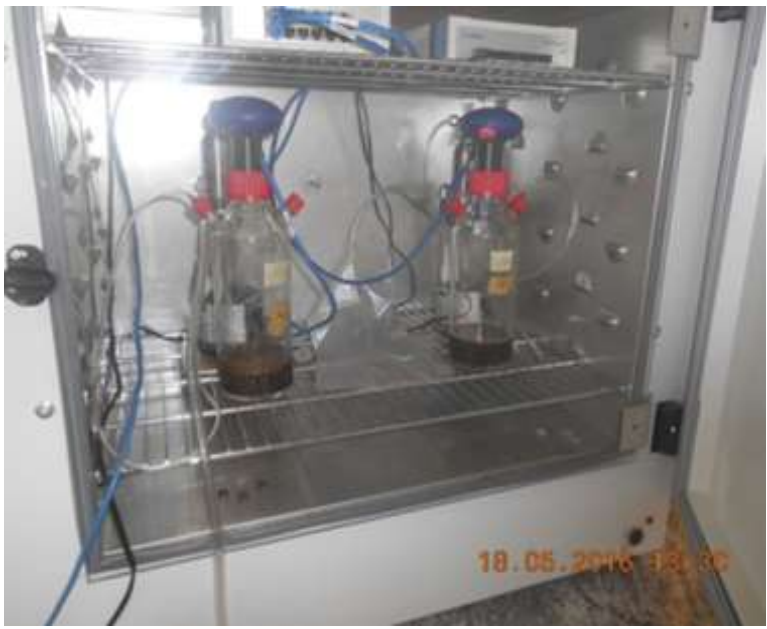

Figure 1:The digester system and some of its components.

\subsection{Sample Preparation}

Samples were prepared by mixing various ratios of bovine blood and rumen contents. To each sample, $100 \mathrm{ml}$ of nutrient medium was added and stirred at $200 \mathrm{rpm}$ for 30 minutes to obtain a homogeneous mixture. The mixing ratios of the seven samples are shown in Table 3. The composition of the nutrient medium is shown in Table 4.

\subsection{Determination of Physicochemical Characteristics of Samples}

The following physicochemical characteristics of the samples were determined. Samples were prepared from cattle blood and rumen contents on three consecutive Wednesdays and the average was determined.

\subsection{1.pH and Temperature}

The $\mathrm{pH}$ and temperature of the samples were determined using the multiparameter from Hanna Instrument (HI9829). Each measurement was taken three times and averaged. All standard laboratory protocols were followed and the manufacturer's instruction manual was strictly followed. Each measurement was repeated three times and the average was determined.

Table 3: Composition of Samples.

\begin{tabular}{|c|c|c|c|}
\hline Sampls & Nutrients $(\mathrm{ml})$ & Blood $(\mathrm{ml})$ & $\begin{array}{c}\text { Rumen Content } \\
(\mathrm{ml})\end{array}$ \\
\hline $\mathrm{S}_{1}$ & 100 & 60 & 0 \\
\hline $\mathrm{S}_{2}$ & 100 & 50 & 10 \\
\hline $\mathrm{S}_{3}$ & 100 & 40 & 20 \\
\hline $\mathrm{S}_{4}$ & 100 & 30 & 30 \\
\hline $\mathrm{S}_{5}$ & 100 & 20 & 40 \\
\hline $\mathrm{S}_{6}$ & 100 & 10 & 50 \\
\hline $\mathrm{S}_{7}$ & 100 & 0 & 60 \\
\hline
\end{tabular}

Table 4: Composition of nutrient medium

\begin{tabular}{|c|c|}
\hline Chemical & Mass $(\mathrm{g})$ \\
\hline $\mathrm{NH}_{4} \mathrm{Cl}$ & 0.53 \\
\hline $\mathrm{KH}_{2} \mathrm{PO}_{4}$ & 0.27 \\
\hline $\mathrm{Na}_{2} \mathrm{HPO}_{4} \cdot 2 \mathrm{H}_{2} \mathrm{O}$ & 0.56 \\
\hline $\mathrm{CaCl}_{2} \cdot 2 \mathrm{H}_{2} \mathrm{O}$ & 0.075 \\
\hline $\mathrm{MgCl}_{2} \cdot 6 \mathrm{H}_{2} \mathrm{O}$ & 0.1 \\
\hline $\mathrm{FeCl}_{2} \cdot 4 \mathrm{H}_{2} \mathrm{O}$ & 0.02 \\
\hline
\end{tabular}

\subsubsection{Total Solids, Moisture Content, Ash Content and Volatile Solids}

To determine TS and moisture content, $50 \mathrm{ml}$ of each wet sample was weighed for its mass (MWS) and dried at a temperature of $105^{\circ} \mathrm{C}$ for twelve hours and the mass of dried sample (MDS) was weighed. The VS and ash content (AC) were also determined by burning the dried samples to ash at a temperature of $550^{\circ} \mathrm{C}$ for four hours and weighing the mass of ash (MA). They were then calculated using equations (1), (2), (3) and (4) as used by [23, 24] in their study. Each measurement was repeated three times and the average was taken.

$$
\begin{gathered}
T S(\%)=\frac{M_{D S}}{M_{W S}} \times 100(1) \\
M C(\%)=\frac{M_{W S}-M_{D S}}{M_{W S}} \times 100(2) \\
A C(\%)=\frac{M_{A}}{M_{D S}} \times 100(3) \\
V S(\%)=\frac{M_{D S}-M_{A}}{M_{D S}} \times 100(4)
\end{gathered}
$$

\subsubsection{Determination of Carbon - Nitrogen ratio (C/N)}

To determine the $\mathrm{C} / \mathrm{N}$ ratio, $50 \mathrm{ml}$ of each sample was used. The organic carbon content of the samples was determined by dry combustion while the nitrogen content of the samples was determined by Kjeldhal Method [25, 24, 4]. Each measurement was repeated three times and the average was determined.

\subsection{Determination of Bio-methane Yield}

Each of the prepared samples was digested in a digester system to assess its biomethane yield. For each sample, the gas counter and infrared sensors (BlueSensBACCom 12) of the digester system recorded the cumulative volume of biogas (ml) and the corresponding cumulative methane concentration (\%), respectively. Measurements were taken in each 1 . The BlueSensBACCom 12 was connected to the BACVis software, which displayed the measured data on a computer 
screen. The biomethane yield of each sample was determined by multiplying the cumulative biogas volume and the cumulative methane concentration.

\section{RESULTS AND DISCUSSION}

\subsection{Physicochemical Characteristics}

The physicochemical characteristics of the samples are shown in Table 5. Itis noticed that there is variability in the characteristics of the samples suggesting that different mixing ratios of the same co-substrates produce substrates with different physicochemical characteristics. This agrees with the findings of $[1,4,13]$ in their studies that different mixing ratios of the same co-substrates produce different physicochemical characteristics. The TS and VS of the samples show that they all had biomethane potentials. In [26], it was recommended that the TS and VS in substrates for biomethane production should be $3-10 \%$ and $75-95 \%$, respectively. In the study of [29] moisture content of substrates increases the biomethanation production therefore higher range of moisture content $(93.5 \pm 0.01$ to $97.0 \pm 0.00)$ suggest that the samples have high biomethane potential. This could also account for the highest biomethane potential of sample $\mathrm{S}_{5}$.

The $\mathrm{C} / \mathrm{N}$ ratio of the samples ranged from $2.6-11.3$, which is close to the findings of [26] in their study that cattle blood and rumen contents have $\mathrm{C} / \mathrm{N}$ of 3.41 and 19.2 , respectively. It was found that the $\mathrm{C} / \mathrm{N}$ ratio of the samples was inversely proportional to the composition of the blood. This indicates that $\mathrm{C} / \mathrm{N}$ ratio depends on the type of substrate. It is known that blood contains more protein and therefore the addition of blood to the rumen contents reduces its $\mathrm{C} / \mathrm{N}$ ratio. Therefore, co-digestion of rumen contents and cattle blood may improve the $\mathrm{C} / \mathrm{N}$ of the substrate. The $\mathrm{pH}$ of the samples was within the optimal $\mathrm{pH}$ values for methanogens $(6.5-8.5)$ and their temperatures were within the mesophilic temperature range $[5,9$,$] . This indicates that the methanogens in the substrates$ had suitable conditions for biomethane production.

\subsection{Bio-methane Potential of the Samples}

The trend of cumulative biomethane production of the samples is shown in Figure 2. Although the trend of cumulative methane production varied among the samples, they all followed the bacterial growth curve. It took some time for each of the samples to begin producing biomethane gas. During this elapsed time, the microorganisms adapted to their new environment before actively engaging in the process. However, $S_{1}, S_{2}, S_{3}$, and $S_{4}$ began production on the first day, while $S_{6}$ and $S_{7}$ began production on the second day and $S_{5}$ on the third day.

Table 5: Physicochemical characteristics of samples

\begin{tabular}{|c|c|c|c|c|c|c|c|c|c|}
\hline Samples & $\begin{array}{c}\text { Moisture } \\
\text { Content }(\%)\end{array}$ & $\begin{array}{c}\text { Total Solids } \\
\text { (\%) }\end{array}$ & $\begin{array}{c}\text { Ash Content } \\
(\%)\end{array}$ & $\begin{array}{c}\text { Volatile } \\
\text { Solids (\%) }\end{array}$ & $\mathrm{pH}$ & $\begin{array}{c}\text { Organic } \\
\text { Carbon }(\%)\end{array}$ & Nitrogen $(\%)$ & $\begin{array}{c}\text { Carbon } \\
\text { Nitrogen } \\
\text { Ratio }\end{array}$ & Temperature (\%) \\
\hline S1 & $95.4 \pm 0.00$ & $4.6 \pm 0.03$ & $6.3 \pm 0.01$ & $93.7 \pm 0.01$ & $8.0 \pm 0.2$ & $47 \pm 0.1$ & $16.8 \pm 0.01$ & $2.8 \pm 0.01$ & $28 \pm 0.01$ \\
\hline S2 & $93.5 \pm 0.01$ & $6.5 \pm 0.01$ & $6.4 \pm 0.01$ & $93.6 \pm 0.00$ & $8.1 \pm 0.00$ & $46.2 \pm 0.01$ & $15.7 \pm 0.01$ & $2.9 \pm 0.01$ & $25.4 \pm 0.01$ \\
\hline S3 & $95.0 \pm 0.01$ & $5.0 \pm 0.01$ & $8.8 \pm 0.00$ & $91.2 \pm 0.01$ & $7.9 \pm 0.01$ & $44.7 \pm 0.01$ & $13.6 \pm 0.01$ & $3.3 \pm 0.01$ & $27.7 \pm 0.01$ \\
\hline S4 & $96.4 \pm 0.01$ & $3.6 \pm 0.04$ & $13.3 \pm 0.01$ & $86.7 \pm 0.00$ & $7.8 \pm 0.01$ & $41.3 \pm 0.01$ & $16.0 \pm 0.00$ & $2.6 \pm 0.01$ & $27.8 \pm 0.01$ \\
\hline S5 & $95.7 \pm 0.01$ & $4.3 \pm 0.05$ & $15.1 \pm 0.01$ & $84.9 \pm 0.00$ & $7.8 \pm 0.00$ & $35.2 \pm 0.01$ & $6.4 \pm 0.00$ & $5.5 \pm 0.01$ & $27.6 \pm 0.01$ \\
\hline S6 & $96.4 \pm 0.01$ & $3.6 \pm 0.03$ & $18.6 \pm 0.00$ & $81.4 \pm 0.00$ & $7.8 \pm 0.01$ & $34.5 \pm 0.01$ & $5.5 \pm 0.01$ & $6.2 \pm 0.00$ & $27.7 \pm 0.02$ \\
\hline S7 & $97.0 \pm 0.00$ & $3.0 \pm 0.01$ & $24.8 \pm 0.00$ & $75.2 \pm 0.00$ & $7.7 \pm 0.00$ & $33.1 \pm 0.01$ & $2.9 \pm 0.01$ & $11.3 \pm 0.01$ & $28.0 \pm 0.01$ \\
\hline
\end{tabular}

$\mathrm{S}_{1}$ did not produce measurable amounts of biomethane gas after the first day until digestion was complete. This may be due to the high digestibility of the blood, allowing the bacteria to digest it quickly [27]. It may also be due to the $\mathrm{pH}$ of the digestion process dropping below the required level (6.5 to 8.5 ) and then inhibiting the process due to the high nitrogen content of the sample. Also, it may be due to lack of balanced nutrients and sufficient microorganisms in the sample. $S_{3}$ and $S_{5}$ finished production on the seventh day, while $S_{4}$ finished production on the eighth day and $S_{1}, S_{2}, S_{6}$ and $S_{7}$ finished production on the fourteenth day. The longer digestion times of $S_{7}$ and $S 6$ may be due to the fact that they contained a high percentage of cellulose and hemicellulose, which require more time to digest.

However, the longer time of $S_{2}$ may be due to the higher proportion of volatile solids [14, 4]. 
$\mathrm{S}_{3}$ increased production gently until the second day, after which it increased steeply until the third day, from which production remained constant. $S_{2}$ and $S_{6}$ gently increased production from the first and second days, respectively, until the fourteenth day, after which production ceased. Day after which production stopped. This could be due to the fact that there was a balanced supply of nutrients and microorganisms that kept the $\mathrm{pH}$ in the appropriate range, which caused the microorganisms to remain active to digest the sample [4, 9]. Meanwhile, the production in $\mathrm{S}_{4}$ increased slightly from the second day until it remained constant on the third day. The variation in the trend of biomethane production of the samples indicated that the different mixing ratios affected the production of biomethane gas.

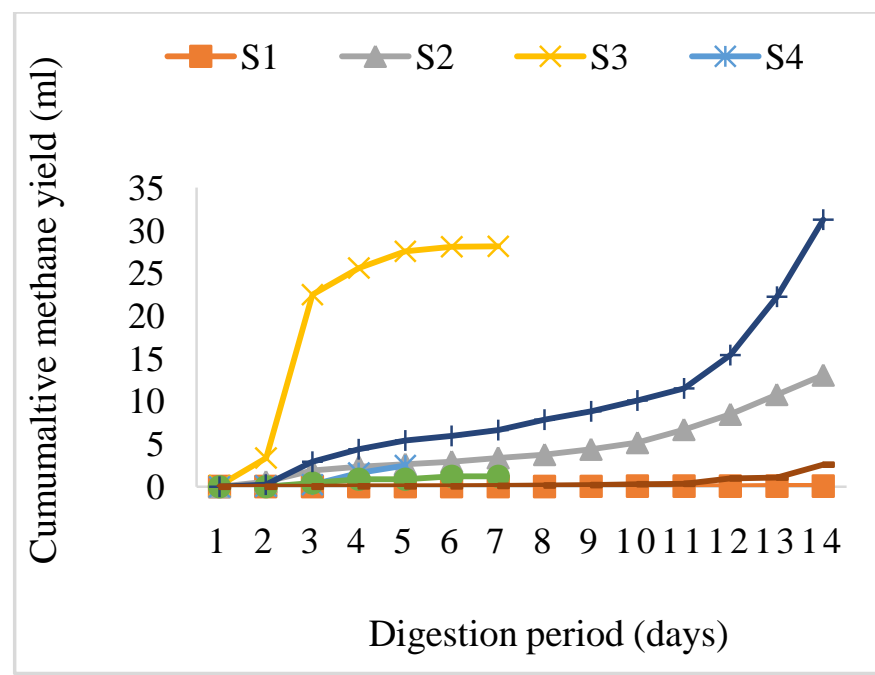

Figure 2: Trend of bio-methane production of samples.

The cumulative biomethane yields of the samples are shown in Table 6 and cattle blood and rumen contents produced the highest biomethane gas, followed by the sample with the ratio of 2:1 $\left(\mathrm{S}_{3}\right)$, while the sample with the ratio of 6:0 $\left(\mathrm{S}_{1}\right)$ produced the least. One-factor ANOVA showed that there was a significant difference in the biomethane yields of the samples $(p<0.05)$. As explained in $[1,4,6,13,28]$, this difference can be attributed to the different mixing ratios of the co-substrates. This is because mixing co-substrates in different ratios results in substrates with different physicochemical characteristics, particularly TS, VS and C/N ratio, creating different environmental conditions for the microbes.

Although sample $\mathrm{S}_{7}$ had a $\mathrm{C} / \mathrm{N}$ of 11.3 , which is within the recommended $\mathrm{C} / \mathrm{N}$ ratio range of 20-30:1 [3], it could not produce higher biomethane compared to $\mathrm{S}_{6}$ as it had the lowest TS and VS. However, $\mathrm{S}_{6}$ had a $\mathrm{C} / \mathrm{N}$ ratio of 6.2 but yielded more biomethane than $S_{7}$, which clearly highlights the influence of TS and VS. C/N ratio provides a balanced $\mathrm{pH}$ environment in which methanogens can operate, while VS is the digestible component of TS, so the higher the percentage of TS and VS, the higher the biomethane gas produced.
Moreover, the required $\mathrm{C} / \mathrm{N}$ optimum depends on the operating conditions and substrate type $[9,11,22] . \mathrm{S}_{1}, \mathrm{~S}_{2}, \mathrm{~S}_{3}$, $\mathrm{S}_{4}$ and $\mathrm{S}_{5}$ had both TS and VS higher than $\mathrm{S}_{6}$ but lower biomethane yield than $S 7$, which could be due to their lower $\mathrm{C} / \mathrm{N}$. When the $\mathrm{C} / \mathrm{N}$ is low, the process suffers from ammonia inhibition, which increases the $\mathrm{pH}$, which inhibits the activities of methanogens $[3,5]$. The above discussion shows that mixing of co-substrates in different ratios produces substrates with different physicochemical properties, thus yielding different amounts of biomethane gas. This clearly shows that different mixing ratios have a significant effect on biomethane production.

Table 6: Cumulative biogas and methane yields of samples

\begin{tabular}{|c|c|c|c|c|}
\hline Sample & $\begin{array}{c}\text { Biogas } \\
\text { Volume }(\mathrm{ml})\end{array}$ & $\begin{array}{c}\text { Methane } \\
\text { Concentration } \\
(\%)\end{array}$ & $\begin{array}{c}\text { Methane } \\
\text { Yield (ml) }\end{array}$ & $\begin{array}{c}\text { Digestion } \\
\text { Period }\end{array}$ \\
\hline $\mathrm{S}_{1}$ & 4.2 & 1.46 & 0.061 & 14 \\
\hline $\mathrm{S}_{2}$ & 90.6 & 14.4 & 13.046 & 14 \\
\hline $\mathrm{S}_{3}$ & 265.6 & 10.6 & 28.154 & 7 \\
\hline $\mathrm{S}_{4}$ & 39.7 & 6.21 & 2.465 & 5 \\
\hline $\mathrm{S}_{5}$ & 8.2 & 14.71 & 1.206 & 7 \\
\hline $\mathrm{S}_{6}$ & 118.3 & 26.41 & 31.243 & 14 \\
\hline $\mathrm{S}_{7}$ & 9.6 & 26.63 & 2.556 & 14 \\
\hline
\end{tabular}

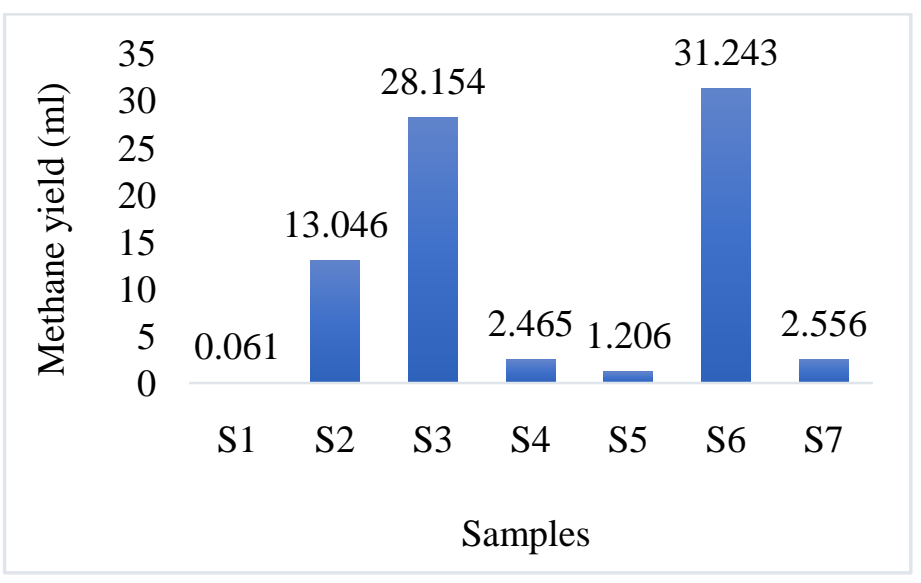

Figure 3: Cumulative bio-methane yields of samples (ml).

\section{CONCLUSION}

There was significant variability in the physicochemical characteristics of the samples, highlighting the fact that different mixing ratios of the same co-substrates have a significant effect on their physicochemical characteristics. The TS, VS and C/N ratio of cattle blood and rumen contents and their different blends ranged from 2.97-17.2\%, 75.17 $95.01 \%$ and $2.6-11.3$, respectively. Their $\mathrm{pH}$ and temperature ranged from $7.58-8.14$ and $25.43-28^{\circ} \mathrm{C}$, respectively. The biomethane yields of the samples gave a mean value of $11.25 \pm 13.34$ which indicates significant variability $(\mathrm{p}<0.05)$. The sample with mixing ratio $1: 5\left(\mathrm{~S}_{6}\right)$ produced the highest biomethane. The study concludes that different mixing ratios 
of cattle blood and rumen contents produce substrates with different physicochemical characteristics and biomethane potentials. The maximum ratio of 1:5 of cattle blood and rumen contents should be considered for the production of biomethane from cattle blood and rumen contents.

\section{ACKNOWLEDGEMENT}

The authors would like to thank Kwame Nkrumah University of Science and Technology - North Rhine Westphalia Collaborative Project for the payment of student stipend. Mr. Joshua Bright Amenorfe and the entire staff of Kumasi Abattoir Company Limited provided necessary assistance in sampling.

\section{REFERENCES}

[1]. Budiyono B., Seno J., Sunarso S. Study on slaughterhouse wastes potency and characteristic for biogas production. International Journal of Waste Resources (IJWR). 2011;1(2).

[2]. International Energy Agency. Energy from biogas and landfill gas. Moss, Norway, vol. (37). (2019) [Online] Available from: $\mathrm{http} / / / \mathrm{www}$.iea-biogas.net. (Accessed on $12^{\text {th }}, 2021$ ).

[3]. Schnurer A, Jarvis A. Microbiological handbook for biogas plants. Swedish Waste Management U. 2010 Dec; 2009:1-74

[4]. Adelard L, Poulsen TG, Rakotoniaina V. Biogas and methane yield in response to co-and separate digestion of biomass wastes. Waste Management \& Research. 2015 Jan;33(1):55-62.

[5]. Al Seadi T, Drosg B, Fuchs W, Rutz D, Janssen R. Biogas digestate quality and utilization. InThe biogas handbook 2013 Jan 1 (pp. 267-301). Woodhead Publishing.

[6]. Gerardi MH. The microbiology of anaerobic digesters. John Wiley \& Sons; 2003 Sep 19.

[7]. House, D. W. (ed.). The complete biogas handbook. [Online] Available from: http://www.completebiogas.com. (2010) (Accessed on $27^{\text {th }}$ September, 2016).

[8]. Zupančič GD, Grilc V. Anaerobic treatment and biogas production from organic waste. Management of organic waste. 2012 Feb 1:128.

[9]. Nwaneri, C. F., Foxon, K., Bakare, B. F. and Buckley, C. Biological degradation processes within a pi latrin. In WISA 2008 conference, Sun City.

[10]. Poulsen T. G., Nizami A. S., Rafique R., Kiely G., Murphy J. D. How can we improve biomethane production per unit of feedstock in biogas plants?. Applied Energy. 2011 Jun 1;88(6):2013-8.

[11]. Latifi P, Karrabi M, Danesh S. Anaerobic co-digestion of poultry slaughterhouse wastes with sewage sludge in batch-mode bioreactors (effect of inoculum-substrate ratio and total solids). Renewable and Sustainable Energy Reviews. 2019 Jun 1;107:28896.

[12]. Manyi-Loh CE, Mamphweli SN, Meyer EL, Okoh AI, Makaka G, Simon M. Investigation into the biogas production potential of dairy cattle manure. Journal of Clean Energy Technologies. 2015 Sep;3(5):326-31.

[13]. Wu X, Yao W, Zhu J. Biogas and $\mathrm{CH} 4$ productivity by codigesting swine manure with three crop residues as an external carbon source. In2010 Pittsburgh, Pennsylvania, June 20-June 23, 20102010 (p. 1). American Society of Agricultural and Biological Engineers.

[14]. Madigan, M. T. and Martinko, J. M. Brock Biology of Microorganisms (11th ed.). London: Pearson Education TLD. (2006); pp. 149-152.

[15]. Díaz JP, Reyes IP, Lundin M, Horváth IS. Co-digestion of different waste mixtures from agro-industrial activities: kinetic evaluation and synergetic effects. Bioresource Technology. 2011 Dec 1;102(23):10834-40.

[16]. Ning Z, Zhang H, Li W, Zhang R, Liu G, Chen C. Anaerobic digestion of lipid-rich swine slaughterhouse waste: Methane production performance, long-chain fatty acids profile and predominant microorganisms. Bioresource technology. 2018 Dec 1;269:426-33.

[17]. Wang X, Li Z, Bai X, Zhou X, Cheng S, Gao R, Sun J. Study on improving anaerobic co-digestion of cow manure and corn straw by fruit and vegetable waste: methane production and microbial community in CSTR process. Bioresource technology. 2018 Feb 1; 249:290-7.

[18]. Ahmad MI, Ejaz O, Ali A, Durrani MA, Khan IA. Anaerobic digestion of waste from a slaughterhouse. Journal of Environmental Chemical Engineering. 2014 Sep 1;2(3):1317-20.

[19]. Bart, F. Feasibility study of pilot biogas plant at Kumasi Abattoir Company Limited, Ghana: final report. Prepared for UNIDO. 2014; pp. 1-90.

[20]. Daniel U, Pasch KH, Nayina GS. Biogas in Ghana: sub-sector analysis of potential and framework conditions. GIZ, Berlin, Germany. 2014.

[21]. Jeung J. H., Moon D. H., Chang S. W. Methane potential of various organic wastes: study of biochemical methane potential (BMP) test before co-digestion. InEnvironmental Science and Sustainable Development: International Conference on Environmental Science and Sustainable Development (ICESSD 2015) 2016 (pp. 283-288).

[22]. Van Reeuwijk, L.P. Procedures for soil analysis. International Soil Reference and Information Centre Technical Paper 9. Wageningen, Netherlands. (2002). [Online] Available from: http://www.isirc.org. (Accessed on $15^{\text {th }}$ January, 2016).

[23]. Cioabla AE, Ionel I, Dumitrel GA, Popescu F. Comparative study on factors affecting anaerobic digestion of agricultural vegetal residues. Biotechnology for biofuels. 2012 Dec;5(1):1-9.

[24]. Schumacher, B. A. Methods for the determination of total organic carbon (TOC) in soils and sediments. Las Vegas, NV: U.S. Environmental Protection Agency, Environmental Science Division, National Exposure Research Laboratory.2002; pp. 3038.

[25]. Weiland P. Biogas production: current state and perspectives. Applied microbiology and biotechnology. 2010 Jan;85(4):849-60.

[26]. Karlsson A, Ejlertsson J. Addition of $\mathrm{HCl}$ as a means to improve biogas production from protein-rich food industry waste. Biochemical engineering journal. 2012 Feb 15;61:43-8.

[27]. Fujishima S, Miyahara T, Noike T. Effect of moisture content on anaerobic digestion of dewatered sludge: ammonia inhibition to carbohydrate removal and methane production. Water Science and $\begin{array}{lll}\text { Technology. } & 2000 & \text { Feb;41(3):119-27. }\end{array}$ 